\title{
Determinants of Technical Inefficiency of Saccos in Kenya: Total Revenue Output Slack Analysis
}

\author{
Leonard Rang'ala Lari, $\mathrm{PhD}$ \\ Moi University-Kenya, School of Business and Economics \\ Dr. Elijah Museve \\ Jaramogi Oginga Odinga University-Kenya, Dept. of Accounting and Finance
}

ACKNOWLEDGEMENT: I thank Dr. Lucy Rono and Prof. Philip Nyangweso of Moi University(Kenya) for their unrelenting guidance and for giving advice towards this work.

\begin{abstract}
This study assessed the determinants of technical inefficiency of Saccos in Kenya. The explanatory research design was applied. The certified annual reports information was collected from a census total of 46 deposit taking Saccos and methods used in estimation of technical inefficiency were both non-parametric DEA and parametric SFA. The $\log$ truncated panel data covered a period of 8 years (2007-2014). The result indicates insignificant influence of all predictor variables on inefficiency given total revenue output (TR) slack as hypothesized in agency, $x-$ inefficiency and intermediation theories. TR slack regression reflects a significant managerial influence as indicated by Gamma (0.999956). However, DEA result of all Saccos showed 0.024 mean inefficiency. The TR slack is key in identifying managerial inefficiency, thus apt for decision making while the relationship between earnings management and the insignificance of predictors given TR slack, should be explored in the future studies. Keywords: Saccos in Kenya, Technical Inefficiency, Total Revenue Output Slack.

DOI: $10.7176 / \mathrm{RJFA} / 11-8-05$

Publication date: April $30^{\text {th }} 2020$

\section{Introduction}

This study seeks to find out the determinants of technical inefficiency given the total revenue slack (inefficiency) as a dependent variable over a period of two eras using both data envelopment analysis (a linear programming approach) and stochastic frontier analysis methods. Inefficiency occurs when a firm (or Sacco) operates outside the frontier of the production technology (Coelli, et al., 1997; Greene, 2012). However, according to Leibenstein, (1966) x-inefficiency is a foregone output due to management inefficiency, while efficiency is a subset of performance (Ozcan, 2008).

The co-operatives development regulation era in Kenya involved the enactment of prudential regulation of Saccos through the Saccos Act, 2008 which legally commenced in September 2009 and gave birth to Sacco Societies Regulatory Authority or SASRA with effect from October 2009 (SSA, 2008; MOCDM, 2013). Chiefly the pre-regulation era covered the period 2010 and before.

According to SASRA (2011) Saccos in Kenya total borrowings from banks in 2010 were estimated at Kshs. 15 billion compared to Kshs. 5.6 billion in 2011. Thus the sector is a key financial channel in fostering access to credit.

On the international front, the Regulatory Authorities and Standards Setting Committees have been able to come up with acceptable information on the financial institutions' efficient operations and risk management criteria (Cooper et al., 2007). World Council of Credit Unions is one similar body that offers related services. Caprio et al., (2003) in their study in 44 countries, postulate that insignificant influence is experienced by banks due to regulation and supervision.
\end{abstract}

\section{Literature Review and Background of the Study}

This study adopted DEA (data envelopment analysis) approach which is linear programming oriented based on a capital rationing argument since the Saccos' external loan capital demand tends to fluctuate periodically (SASRA, 2011; Brealey and Myers,1981).

A star organization identification assists in identifying the managers' rewards and the kind of good practices employed or which can be copied by inefficient firms in the industry. Dexterity also aids in identifying profitable areas of organizations to invest their assets (Healy, 1988). The efficiency measurement system is able to identify optimum resource allocation besides setting targets.

The inefficiency measurement aids entities in the identification of best practice, identification of poor practice, in setting targets, in resource allocation and in monitoring efficiency changes periodically (Beasley, 1996). However, Barus et al. (2017) argue that the financial performance of Saccos in Kenya is not significantly affected by management efficiency. 
A study by Johnson and Nino-Zarazua (2008) has shown that in Kenya $12.8 \%$ of the population save with Saccos and $4.1 \%$ borrow from them. In addition, Saccos in Kenya are principally either based on common bonds of farming or employment (Johnson and Nino-Zarazua, 2008). It is also worth noting that in Africa South of the Sahara, the Kenyan Saccos movement has the second largest number of Saccos following Ethiopia (Woccu, 2009). For instance, in March 2013, the number of Saccos in Tanzania were 5,559 (Magali, 2014) while in Kenya the total number of registered Saccos were estimated at about 7,500 in August 2013 (SASRA, 2013).

There are a few studies in the area of co-operatives since 1990 (Evans, 2002; Petrie, 2002; Emerson and Wiren, 2005). Further, these studies are basically based on absolute performance measures and interview responses from the stakeholders. The situation is slowly changing as other researchers are now coming up especially based on ratios, efficiency and multiple regression such as (Tesfamariam et al., 2013; Kivuvo and Olweny, 2014; Mirie, 2014; Marwa and Aziakpono, 2015).

The down turn in an economy increases the inefficiency of money-making enterprises than it does to cooperatives. Co-operatives have shown their ability to provide services to their members even during the financial crisis. However, in developing countries of Africa the co-operatives' resilience to the financial crisis is not strong and this coupled with the internal political impact or mismanagement within co-operatives means, the crisis gets worse (Wanyama et al., 2009). The number of women on the board predictor is picked as a variable although there is conflicting studies result in the effect of gender diversity on the boards. Adams and Ferreira (2008) argue that on average the presence of both genders on the boards in companies having no takeover prevention mechanism does experience inefficiency. On the contrary, Higgs (2003) postulates that performance improvement result from gender diversity in the board room while Gompers et al. (2003) conclude that gender is a good performance contributor in organizations with non-strong shareholder rights.

The latest liberalization of the co-operatives movement is in the area of devolution of co-operatives regulation from the national level to County levels as enshrined in the Constitution of Kenya 2010 (COK, 2010; MOCDM, 2013). These changes are aimed at the reduction of technical inefficiency. However, despite the existence of the prudential regulations, the deposit-taking Saccos have continued to reveal mixed levels of management inefficiency (SASRA, 2013). In addition, a study by Chavez, (2006) indicates that the Kenya Sacco sub-sector reflects a seriously weak financial performance position that is pervasive.

\subsection{Theoretical Review}

This research was guided by the theory of agency, $x$-inefficiency and the financial institutions' efficiency measurement theories; more precisely, the intermediation theory. Other discussed models relevant to this research are the financial institutions' prudential monitoring standards. However, the state agency of deposit-taking Saccos in Kenya advocates for the adoption of Camels Prudential Reporting Standards (Kivuvo and Olweny, 2014). In addition, this research used the BCC analysis based on inefficient results of DEA as dependent variables (Banker et al., 1984) which were used to identify the variables that best measure the pure technical inefficiency of the Saccos by running a truncated-normal regression given a census of 46 deposit taking Saccos that had attained the front office services activities (FOSA) operation requirements.

\subsection{Statement of the Problem}

The co-operatives sector in Kenya has gone through a historical development process known for inefficiency. The inefficiency was more prevalent during the liberalization period (Wanyama, 2009). As a result, the need for regulation and inefficiency understanding becomes necessary to ensure the stability of Saccos' sub-sector and guaranteed efficiency. This study is also an addition to the ongoing inefficiency of Saccos' research in the Kenyan context.

A few past researchers in Kenya have studied Saccos without utilizing SFA and identifying benchmark Saccos, they based on performance: (Olando et al., 2012; Karanja, 2013; Njagi et al., 2013; Nyambere, 2013; Okibo and Karagu, 2014; Barus et al., 2017). These studies ignored the aspect of inefficiency measurement. A more recent study by Mirie (2014) indicates Saccos' inefficiency in Kenya being within a range of 0.44 and 0.0. However, it failed to consider other specific variables of (in)efficiency measurement such as the economic indicators, gender diversity on Saccos' boards, and net profit to total assets ratio besides the extent of management influence on Saccos' inefficiency. Marwa and Aziakpono (2015) studied technical and scale efficiency of Saccos in Tanzania using DEA and concluded that on an average majority of Saccos scored 0.48 pure technical inefficiency and at least $75 \%$ of Saccos exhibited an increasing return to scale. A study by Kipesha, (2012) arrived at the inefficiency of between 0.855 and 0.31 for the Tanzanian micro finance bodies. Similar researches in the banking industry in sub-Saharan Africa opine that technical inefficiency falls between 0.4 and 0.1 (Moffat, 2008; Kamau, 2011).

Tesfamariam et al. (2013) postulate that the efficiency of rural Saccos in Ethiopia indicated that efficiency is affected by both the location and size of Saccos. They also opine that on average inefficiency ranged between 0.787 and 0.741 for small Saccos, while larger Saccos recorded lower inefficiency compared to smaller ones. A 
study like Magali (2014) in Kenya also suggested future studies in the area of Saccos' technical efficiency using the SFA.

Magali (2014) concludes that there is no prior studies on Saccos in East Africa that have assessed the influence of regulation on Sacco's performance while at the same time considering the impact of rural and urban areas' location of Saccos on performance. He further argues that scholars should extend to econometrics to expand Saccos modeling. A few studies such as Marwa and Aziakpono (2015) in Tanzania, and Tesfamariam et al. (2013) in Ethiopia, have researched on the efficiency of Saccos in the African continent.

Considering the above-mentioned gap of prior studies, this study examined whether Saccos were more inefficient during the regulation era than the pre-regulation era. The stars Saccos were also identified. Essentially this study assessed the determinants of the inefficiency of FOSA. Specifically, the pure technical efficiency (a cost-efficiency measure) model was utilized (Coelli et al., 1997).

The creation of SASRA as a regulator of Saccos has been necessitated by the challenges of a liberalized economy. The question that arises then is: to what extent has the Saccos' market become efficient? These facts then point to the need to measure and determine the Kenyan Saccos' pure technical inefficiency or efficiency. Pure technical efficiency occurs when a firm operates under variable returns to scale. This study sets deliberate standards on how Saccos in Kenya can be monitored and peers emulated to ensure efficiency in their operations.

\subsection{The General Objective}

The general objective of this study is to establish the determinants of technical inefficiency of deposit taking Saccos in Kenya, given total revenue slack (an output inefficiency) as a dependent variable.

\subsection{The Specific Objectives}

The specific objectives of this study are as follows:

1. Measure the extent of managerial inefficiency over the pre-regulation and regulation eras.

2. Establish the effect of macro-economic variables on the Saccos' total revenue output inefficiency.

3. Determine the effect of Saccos' specific predictor variables on Saccos' total revenue output inefficiency.

\subsection{Research Hypotheses}

The study also tests the hypotheses that:

1. $\mathrm{H}_{01}$ : The Saccos operation is not influenced by managerial influence (inefficiency) as measured over the two eras.

2. $\mathrm{H}_{02}$ : There is no strong relationship between the Saccos' macro-economic variables and total revenue output inefficiency dependent variable.

3. $\mathrm{H}_{03}$ : There is no strong relationship between the Saccos' specific independent variables and total revenue output inefficiency dependent variable.

\subsection{The Concept of Technical Inefficiency}

The conceptual framework model in figure I reflects the dependent variables derived from the output inefficiencies (specifically, the TR slack), and independent variables relationship. The frontier preliminary analysis involved determination of correlation between each of the Saccos' variance regressors and prime regressors, and if a high correlation is discovered, such specific independent variable (prime regressor) is removed from the second or final stage regression process. However, no variable was removed and this estimation was also internalized within the Stata14.1. Further, prime regressors are also assumed to be measurement errors free (Cooper et al., 2007). 


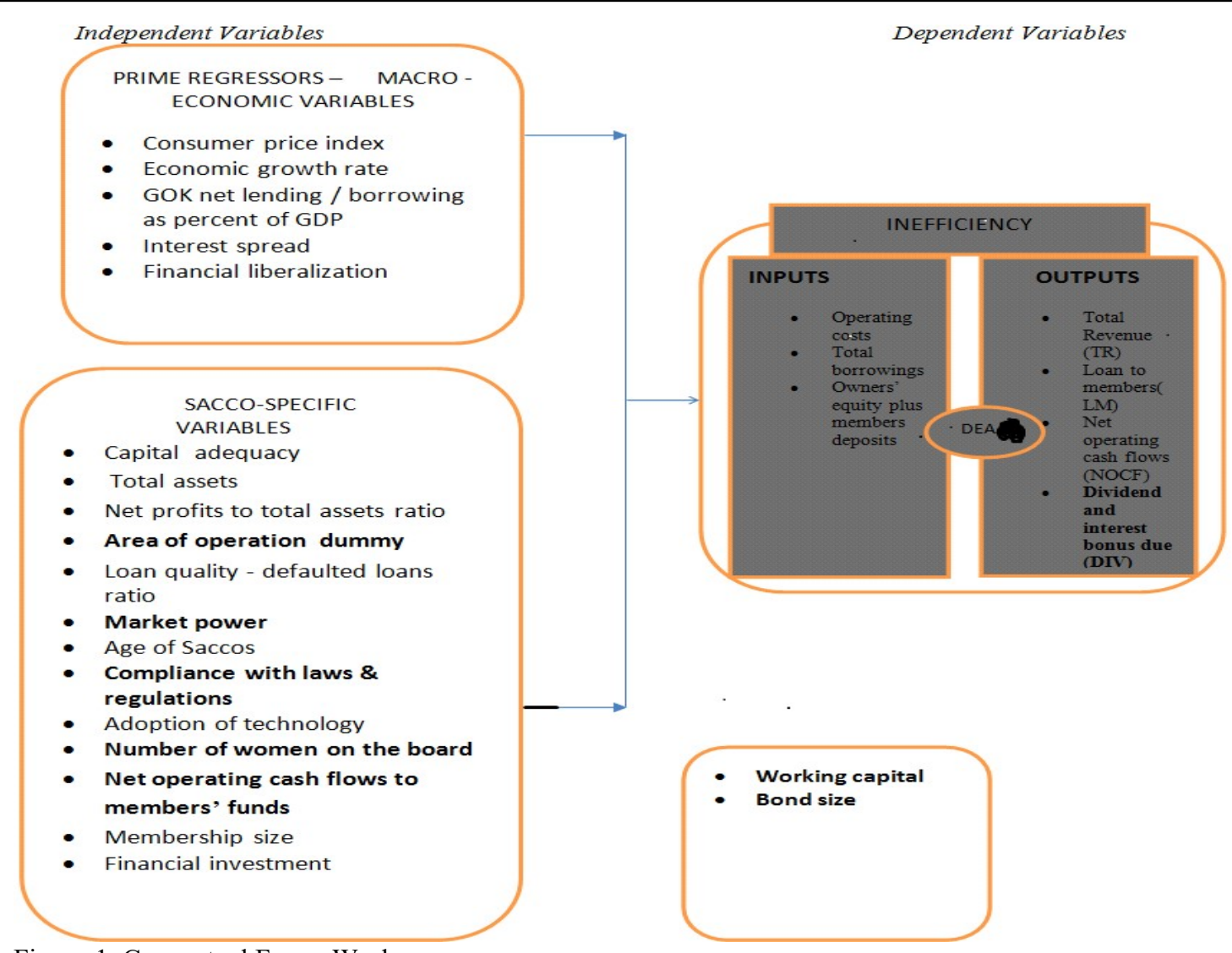

Figure-1. Conceptual Frame Work

Source: Researcher, (2015)

\section{Research Methodology}

\subsection{Design}

This explanatory study used a balanced panel data. The explanatory study research design was employed in soliciting for secondary information from the audited annual reports and websites of the regulators on determinants of Saccos' inefficiency in Kenya. This study utilized a second stage data envelopment analysis by subjecting the resultant data to SFA (stochastic frontier analysis). An econometric approach in estimation of Saccos' inefficiency determinants was utilized since SFA stipulates the functional form of cost or production frontier (Cummins and $\mathrm{Zi}, 1998)$. The panel data has benefit of assisting in studying the behavior of each Sacco on cross-sectional and time-series or year basis (Ongore and Kusa, 2013). Further, the study utilized a census technique whereby 46 licensed Saccos under the regulator's control within the two periods of study running from 2007 to 2010, and 2011 to 2014(a span of 8 years) were selected.

\subsection{Model Specification}

The estimation of inefficiency was carried out utilizing the Cobb-Douglas cost frontier cross- sectional panel data of Saccos over two periods. Truncated-normal distribution was assumed Coelli et al. (2005) and Cooper et al. (2011). Stata 14.1 was used to decompose errors (Jondrow et al., 1982; Pascoe et al., 2003). The SFA was based on Cobb-Douglas logarithmic model Iny ${ }^{*}=\beta_{0}+\sum_{1}^{k} \beta \mathrm{r}_{\mathrm{InZ}} \mathrm{kjt}_{\mathrm{jt}}+\mathrm{V}_{\mathrm{rjt}}+\mathrm{U}_{\mathrm{rjt}}$ (1); where: $\beta_{\mathrm{r}}$ is the frontier deterministic component, $\mathrm{V}_{\mathrm{rjt}}$ is stochastic part and $\mathrm{U}_{\mathrm{rit}}$ presents the shortfall observed individual fails to hit the optimum (frontier), $\mathrm{j}(\mathrm{j}=1, \ldots, \mathrm{n})$ is the cross-sectional identifier, $\mathrm{t}(\mathrm{t}=1, \ldots, \mathrm{t})$ is time identifier , $\mathrm{y}^{*}$ is the first stage optimal slack(normalized) in output $\mathrm{r}$ of $\mathrm{DMU}_{\mathrm{j}}$ (decision making unit $\mathrm{j}$ ), $\beta \mathrm{o}$ is the intercept of output slack equation, 'In' is natural logarithm, and $\mathrm{Z}$ has $\mathrm{k}(\mathrm{k}=1, \ldots, \mathrm{k})$ observable environmental factors (Battese and Coelli, 1995).

The specific forms of equation (1) estimated for research of determinants of technical inefficiency of Saccos is thus written as: $I_{I n}\left(T R_{j t}\right)=\beta_{0}+\beta_{I I n}\left(a g e_{j t}\right)+\beta_{2 I n}\left(c a_{j t}\right)+\beta_{3 I n}\left(t a_{j t}\right)+\beta_{4}\left(a o_{j t}\right)+\beta_{5 I n}\left(\operatorname{lp}_{j t}\right)+\beta_{6 I n}\left(m p_{j t}\right)+\beta_{7 I n}\left(c l r_{j t}\right)+\beta_{8}$

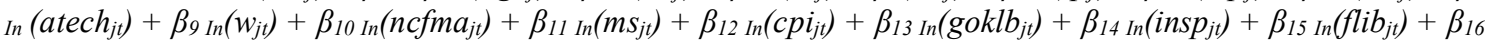
${ }_{I n}\left(f_{j t}\right)+\beta_{17 I n}\left(n p t a_{j t}\right)+\beta_{18 I n}\left(g d p_{j t}\right)+\beta_{19 \text { In }}\left(w c_{j t}\right)+\beta_{20 I n}\left(b_{o n d} t\right)+V_{j t}+U_{j t}$ 


\subsection{DEA Result}

The study examined the inefficiency and efficiency census of 46 Saccos using a non-parametric variable return to scale (VRS) - BCC or technical inefficiency model. The model utilized was output oriented whereby the output included: total revenue, loans to members, net operating cash flows, and divided plus interest on members' deposits while inputs were: operating costs, total borrowings and owners' equity plus members' deposits. The panel data model utilized using Stata DEA software was derived from 368 observations while technical inefficiency was measured on scale of 0 up to a maximum of 1. DEA result indicated that a total of 24 out of 46 Saccos were strongly efficient and exhibited zero slacks across all output variables and this was attributed to net operating cash flows reported for the corresponding years.

\subsection{Output Description}

Table I presents the mean output as expressed in TR (total revenue slack), LM (loan to members' slack), NOCF (net operating cash flows slack), and DIV (dividend slack) in Kshs.Million for years 2007 to 2014. As reflected in the table I the mean TR, LM, NOCF, DIV for the Saccos sub-sector (FOSA) was 427, 2234, 1038, and 148 respectively. The overall mean score as a percentage of the Saccos' sub-sector sum was $0.18 \%$ across all outputs. Table-I. Eight Years Mean Outputs of Saccos in Kenya

\begin{tabular}{|c|c|c|c|c|}
\hline \multicolumn{5}{|c|}{ Eight Years Average Outputs of Saccos in Kenya } \\
\hline & TR & LM & $\mathrm{NOCF}$ & DIV \\
\hline Mean score & 427 & 2234 & 1038 & 148 \\
\hline Standard Deviation & 1114 & 6720 & 1380 & 596 \\
\hline Mean as a $\%$ of Industry Sum & 0.18 & 0.18 & 0.18 & 0.18 \\
\hline Observations & 368 & 368 & 368 & 368 \\
\hline
\end{tabular}

Source: Researcher, (2015)

\subsection{Descriptive Statistics}

The descriptive statistics in table II presents specific variables that determine the inefficiency of Saccos in Kenya. As reflected in the table II, the mean capital adequacy of Saccos in Kenya was 21\%. The percentage is above $10 \%$ set by SASRA (SSR, 2010). This indicates that Saccos in Kenya running FOSA hold more capital than required. This was an indication that Saccos running FOSA in Kenya were risk averse and in return earn less profit. On the contrary the ratio of net profit to total assets is high at $22 \%$, an indication of mixed result pointing to the direction of inefficiency or earnings management (Schilit,2002 and Brown, 2006). The market power of $2 \%$ is far below $70 \%$ standard market share that indicates a few firms being in control of an industry (Ogebe et al., 2013). Further, the average women on the board stood at $20 \%$ with standard deviation of $12 \%$. This is a low number and has little influence on Saccos' inefficiency (Higgs, 2003).

The table II also reflect mean defaulted loans ratio being 3\% which is below $4 \%$ according to census research on Saccos in Meru County Kenya (Olando et al., 2012). This is an indication that the regulator role has played an impact in reducing the default risks to lower percentage and may point to the direction that in this sub-sector, loan guarantors carry next to $97 \%$ burden in case of any default thus lowering LP effect on inefficiency. According to Brown and O'Connor (1999) higher default rate lowers the relative efficiency of a money market. The average age of Saccos was shown as 27.07 years with a standard deviation of 9.3 years, a reflection of a young industry. Magali (2014) posit that age and size are correlated in the same direction and that a rise in age of a small firm has a positive relation with efficiency.

Table-I I. Descriptive Statistics of Predictor Variables

\begin{tabular}{l|l|l|l|l|l|l|l|l|l|l}
\hline \multicolumn{1}{l}{ Descriptive Statistics of Predictor Variables } \\
\hline Variables & CA & Bond & NPTA & MP & W & MS & LP & Age-Yrs. & GOKLB & \\
\hline Mean & 0.21 & 5.33 & 0.22 & 0.02 & 0.20 & 21245 & 0.03 & 27.07 & 2.72 & \\
\hline $\begin{array}{l}\text { Standard } \\
\text { Deviation }\end{array}$ & 0.15 & 10.78 & 0.02 & 0.04 & 0.12 & 36063 & 0.09 & 9.30 & 1.37 & \\
\hline Observations & 368 & 368 & 368 & 368 & 368 & 368 & 368 & 368 & 368 & \\
\hline
\end{tabular}

Source: Researcher, (2015)

\subsection{Operationalization of the Study Variables}

The study measurements used to operationalize the study specific variables are as indicated in table III. 
Table-I I I. Study Variables

\begin{tabular}{l|l}
\hline Study Variable & Measurement \\
\hline Capital adequacy(CA) & Core capital to total assets \\
\hline Total assets(TA) & Total assets \\
\hline NPTA & Net profit to total assets \\
\hline Area of operation (AO) & Dummies 1-City; 0 -Urban \\
\hline Loan quality(LP) & Loans provision \\
\hline Market power(MP) & Sacco deposit to total FOSA deposits \\
\hline Age & Number of years in operation \\
\hline CLR & Compliance with regulations(average scores) \\
\hline Atech & Computerization expenditures \\
\hline W & Fraction of women on the board \\
\hline NCFM & Net operating cash flows to members funds \\
\hline MS & Number of members \\
\hline WC & Current assets less current liabilities \\
\hline Bond & Size of contributing common bond employers \\
\hline FI & Financial investments total amount \\
\hline
\end{tabular}

Source: Researcher, (2015)

\subsection{Model Testing and Random Effects Estimation}

The study test carried out to ensure that the data fits the linear regression assumptions include:

\subsubsection{Normality Test}

The study tested for normality using Shapiro-Francia W test as the observations were less than 5000 and greater than 10 under log normality condition (Stata, 2015). The result obtained is as shown in table IV which indicates that only two variables reflected p-values greater than 0.05 thus a possibility of heteroscedasticity. The data used also underwent natural logarithm transformation.

Table-IV. Testing Study Variables for Normality

\begin{tabular}{l|l|l|l|l}
\hline & Shapiro-Francia & W test for normal data & & \\
\hline Variable & $\mathrm{W}^{\prime}$ & $\mathrm{V}^{\prime}$ & $\mathrm{Z}$ & Prob. > z \\
\hline Age & 0.89443 & 29.112 & 7.251 & 0.00001 \\
\hline Ca & 0.99163 & 2.307 & 1.798 & 0.03608 \\
\hline Ta & 0.98818 & 3.259 & 2.541 & 0.00553 \\
\hline Npta & 0.84112 & 43.814 & 8.13 & 0.00001 \\
\hline Ao & 1 & 0 & -58.997 & 1 \\
\hline Lp & 0.74358 & 70.711 & 9.16 & 0.00001 \\
\hline Mp & 0.93325 & 18.406 & 6.265 & 0.00001 \\
\hline Clr & 0.70719 & 80.744 & 9.445 & 0.00001 \\
\hline Atech & 0.68281 & 87.468 & 9.617 & 0.00001 \\
\hline W & 0.98012 & 5.482 & 3.66 & 0.00013 \\
\hline Ncfma & 0.34704 & 180.06 & 11.171 & 0.00001 \\
\hline Ms & 0.99448 & 1.522 & 0.904 & 0.1831 \\
\hline Cpi & 0.95686 & 11.896 & 5.326 & 0.00001 \\
\hline Gdp & 0.61534 & 106.072 & 10.032 & 0.00001 \\
\hline Goklb & 0.62312 & 103.927 & 9.988 & 0.00001 \\
\hline Insp & 0.90277 & 26.813 & 7.074 & 0.00001 \\
\hline Flib & 0.53518 & 128.178 & 10.439 & 0.00001 \\
\hline Wc & 0.13271 & 239.162 & 11.781 & 0.00001 \\
\hline Bond & 0.92325 & 21.164 & 6.565 & 0.00001 \\
\hline Fi & 0.80534 & 53.678 & 8.567 & 0.00001 \\
\hline So & & & &
\end{tabular}

Source: Researcher, (2015)

\subsubsection{Multicollinearity Test}

The possibility of strong relationship between predictor variables was checked using the correlation CoefficientSpearman rho. The result indicated a few scores of higher than or equal to 0.8 , thus reflecting lack of serious multicollinearity among variables. Thus coefficients computed were considered reliable. A second nonobservational method was utilized in testing for multicollinearity that is, variation inflation factor and the result for each dependent variable is as indicated in table V. This result indicates TR slack regressed against all 
independent variables confirm lack of serious multicollinearity possibility for all predictors except GOKLB, CLR and TA. Studies have also indicated that a VIF above 20 is the one that should be categorized as challenging (Greene, 2012). GOKLB and CLR being above 20 are the only two most challenging thus ignored, given that the covariates VIF mean will not fall below 4 even on elimination of all the three challenging items. However, an average VIF of around 4 is not problematic (Stata, 2015).

Table-V. Dependent Variable-TR Slack and all Covariates VIF Results

\begin{tabular}{l|l}
\hline Covariates & Variation Inflation Factor(VIF) \\
\hline goklb & 46.13 \\
\hline clr & 26.38 \\
\hline mp & 20.49 \\
\hline gdp & 17.87 \\
\hline cpi & 10.02 \\
\hline age & 10.01 \\
\hline flib & 8.73 \\
\hline ao & 7.89 \\
\hline w & 7.18 \\
\hline insp & 5.57 \\
\hline ms & 5.44 \\
\hline ca & 5.36 \\
\hline fi & 4.44 \\
\hline ncfma & 3.64 \\
\hline lp & 2.47 \\
\hline bond & 2.03 \\
\hline npta & 1.99 \\
\hline atech & 1.91 \\
\hline wc & 1.86 \\
\hline Mean VIF & 1.73 \\
\hline Sourc: Rear & 9.56 \\
\hline
\end{tabular}

Source: Researcher, (2015)

\subsubsection{Random Effects Estimation}

The Hausman-Taylor estimator method was used to confirm that none of the covariates of the panel-level models are correlated with unobserved panel-level random effects $\left(\mathrm{U}_{\mathrm{rjt}}\right)$, although some of the covariates may be associated with the unobserved individual-level random effect. The result of the estimation summary is as indicated in table VI. The result indicates that the unobserved random effect $\delta \mu=0.9562$ greater than $\delta_{\text {error }}=.0 .0932$, suggesting that large portion total error variance is as a result of $U_{\text {rjt, }}$ idiosyncratic error. Therefore, the fixed effects model and random effects model in the panel data are different $\left(\mathrm{H}_{1}\right)$ and random effects model is preferred (that is, reject $\mathrm{H}_{0}$ ). Meaning the ordinary least squares (OLS) would give inconsistent result (Stata, 2015).

Table-VI. Hausman Taylor Estimation -Slack TR and Covariates

\begin{tabular}{l|l}
\hline Summary of Items & Result \\
\hline Number of observations & 54 \\
\hline Number of groups & 23 \\
\hline Random effect & Urjt $\sim$ iid \\
\hline Wald chi sq.(20) & 43.40 \\
\hline Prob. $>$ chi sq & 0.0018 \\
\hline Sigma $U_{\text {rjt }}\left(\mathrm{V}_{\text {rit }}\right)$ & 0.9562 \\
\hline Sigma error & 0.0932 \\
\hline$R_{\text {ho* }}$ & 0.9906 \\
\hline Source: Researcher
\end{tabular}

Source: Researcher, (2015). * Fraction of value due to Urjt

\section{Spearman Correlation and other Key Findings}

The results of the correlation indicated that the working capital or insolvency measure had weak negative correlation of -0.2739 with TR slack while women on the board at +0.562 . This correlation is not in compliance to a prior study which postulate that higher number of women on the board decreases inefficiency depending on the type of industry (Ferreira and Adams, 2009). Capital adequacy is also negatively correlated (-0.4108) to dependent variables of TR slack in line with the expectation of the agency, financial intermediation and efficiency theories (Famma, 1980; Magali and Pastory, 2013). The correlation also indicates that there is a negative 
relationship between log of total assets (size measure) and the TR output slack (or inefficiency) at -0.4108 . Similar results were observed with NOCF slack. This finding ties well with prior study which found out an existence of positive relationship between the size of Saccos and efficiency (Magali, 2014).

\subsection{OLS Regression Correlation and Stochastic Frontier Analysis Results}

The correlation between environmental factors (prime regressors) and specific predictor variables was tested for purpose of eliminating highly correlated prime regressor(s). The results indicated are mixed with only one significant variable of compliance with regulation having $\mathrm{R}^{2}$ adjusted of 0.868 as shown in table VII. This lend to retention of all environmental predictor variables in the final model of this study. This study finding in table VIII also indicates that women on the board decrease results to increases in TR inefficiency although insignificant. The influence of macroeconomic variables to dependent variable of TR slack is also insignificant.

The Gamma of 0.999956 is not far away from one. Therefore, hypothesis $\mathrm{H}_{01}$ is rejected, $\mathrm{H}_{02}$ is also accepted while $\mathrm{H}_{03}$ is also accepted, all at $95 \%$ level of confidence. The result utilized 54 observations out of a total of 368 and indicates all predictors jointly influence inefficiency given Wald Chi sq. (20) $=36.34$ (p-value 0.014). However, the influence of control variables on TR slack variable is also insignificant. The mean of truncatednormal distribution $\left(\mathrm{m}_{\mathrm{u}}\right)$ value of -289.902 is far from zero, thus a reflection of inability for study data to reduce to OLS regression Stata (2015).

Table-VII. Regress Predictors: CPI, GDP, GOKLB, INSP, \& FLIB

\begin{tabular}{l|l|l|l}
\hline Dependent Variables & Adj. $\mathbf{R}^{\mathbf{2}}$ & Prob. $\mathbf{~ F}$ & OBS. (95\% Conf.Int.) \\
\hline Age & 0.04 & 0.0011 & 368 \\
\hline Ca & 0.01 & 0.122 & 368 \\
\hline Ta & 0.06 & 0.0001 & 368 \\
\hline Npta & 0.012 & 0.097 & 368 \\
\hline Ao & -0.014 & 1.000 & 368 \\
\hline Lp & 0.118 & 0.000 & 368 \\
\hline Mp & -0.0005 & 0.439 & 368 \\
\hline Clr & $\mathbf{0 . 8 6 8}$ & 0.000 & 368 \\
\hline Atech & 0.046 & 0.0005 & 368 \\
\hline W & -0.010 & 0.93 & 368 \\
\hline Ncfma & -0.006 & 0.699 & 368 \\
\hline Ms & 0.065 & 0.000 & 368 \\
\hline Wc & -0.0005 & 0.441 & 368 \\
\hline Bond & -0.0000 & 0.419 & 368 \\
\hline Fi & 0.0371 & 0.0022 & 368 \\
\hline Source & & & \\
\hline
\end{tabular}

Source: Researcher, (2015) 
Table-VIII. Time Varying Inefficiency Model-Regression of Total Revenue Output Slack to Predictor Variables: with Control Variables

\begin{tabular}{|c|c|c|c|c|c|c|}
\hline $\begin{array}{l}\text { Observations } \\
=54\end{array}$ & & & & Wald chi & ${ }^{2}(20)=$ & 36.34 \\
\hline Log likelihood & 53.1836 & & & Prob $>c$ & $\mathrm{hi}^{2}$ & $0.014 *$ \\
\hline Slack TR & Coef. & $\begin{array}{l}\text { Std } \\
\text { Err. }\end{array}$ & $\mathrm{Z}$ & $\overline{\mathrm{P}>}>\mathrm{z} \mid$ & [95\% Conf. & Interval] \\
\hline age & -0.09643 & 0.090336 & -1.07 & 0.286 & -0.27348 & 0.080628 \\
\hline $\mathrm{ca}$ & 0.020402 & 0.037699 & 0.54 & 0.588 & -0.05349 & 0.09429 \\
\hline ta & 0.021491 & 0.028263 & 0.76 & 0.447 & -0.0339 & 0.076886 \\
\hline npta & -0.26236 & 0.262064 & -1 & 0.317 & -0.77599 & 0.251278 \\
\hline ao & 0.167405 & 0.086679 & 1.93 & $0.053 * *$ & -0.00248 & 0.337292 \\
\hline $1 \mathrm{p}$ & 0.000034 & 0.00191 & 0.02 & 0.986 & -0.00371 & 0.003778 \\
\hline $\mathrm{mp}$ & 0.013804 & 0.02036 & 0.68 & 0.498 & -0.0261 & 0.05371 \\
\hline $\mathrm{clr}$ & -0.01868 & 0.24148 & -0.08 & 0.938 & -0.49197 & 0.454609 \\
\hline atech & 0.00281 & 0.002263 & 1.24 & 0.214 & -0.00162 & 0.007245 \\
\hline $\mathrm{W}$ & -0.08923 & 0.06838 & -1.3 & 0.192 & -0.22325 & 0.044795 \\
\hline ncfma & 0.034894 & 0.088621 & 0.39 & 0.694 & -0.1388 & 0.208588 \\
\hline $\mathrm{ms}$ & -0.02643 & 0.020443 & -1.29 & 0.196 & -0.06649 & 0.013641 \\
\hline cpi & 0.014716 & 0.044597 & 0.33 & 0.741 & -0.07269 & 0.102125 \\
\hline gdp & -0.01532 & 0.024155 & -0.63 & 0.526 & -0.06266 & 0.032021 \\
\hline goklb & 0.005461 & 0.06479 & 0.08 & 0.933 & -0.12153 & 0.132447 \\
\hline insp & 0.678677 & 0.377107 & 1.8 & 0.072 & -0.06044 & 1.417793 \\
\hline flib & -0.1093 & 0.090966 & -1.2 & 0.23 & -0.28759 & 0.068989 \\
\hline Wc & 0.062727 & 0.05055 & 1.24 & 0.215 & -0.03635 & 0.161802 \\
\hline bond & 0.026835 & 0.025506 & 1.05 & 0.293 & -0.02316 & 0.076826 \\
\hline fi & -0.00476 & 0.005522 & -0.86 & 0.388 & -0.01559 & 0.006061 \\
\hline cons & -3.44586 & 1.88186 & -1.83 & 0.067 & -7.13424 & 0.242517 \\
\hline$/ \mathrm{mu}$ & -289.902 & & & &. & \\
\hline /eta & -0.44029 & 0.154823 & -2.84 & 0.004 & -0.74374 & -0.13685 \\
\hline $\operatorname{lnsigma~}^{2}$ & 4.107683 & 0.011205 & 366.61 & 0.00 & 4.085723 & 4.129643 \\
\hline /ilgtgamma & 10.02409 & 0.258082 & 38.84 & $0.00 *$ & 9.518262 & 10.52993 \\
\hline sigma $^{2}$ & 60.80566 & 0.681295 & & & 59.4849 & 62.15575 \\
\hline gamma & 0.999956 & $1.14 \mathrm{E}-05$ & & & 0.999927 & 0.999973 \\
\hline sigma $u^{2}$ & 60.80297 & 0.681299 & & & 59.46765 & 62.13829 \\
\hline sigma_v ${ }^{2}$ & 0.002695 & 0.000695 & & & 0.001333 & 0.004056 \\
\hline
\end{tabular}

Source: Researcher, (2015). Significance levels: $1 \% *, 5 \% * *$ and $10 \% * * *$

\section{Conclusion}

The general objective of this study was to establish the determinants of technical inefficiency of deposit taking Saccos in Kenya, given a total revenue slack (an output inefficiency) as a dependent variable. To attain this objective, eight years' panel data for 46 Saccos was analyzed by the help of data envelopment analysis and stochastic frontier model using Stata14.1 software. Therefore, the effect of five macro-economic variables, thirteen specific Saccos' predictors and two control variables against dependent variable of TR slack were evaluated. The dependent variable slacks (inclusive of TR) were determined using data envelopment analysis model in Stata14.1. It was found that 13 out of 46 Saccos scored strong technical efficiency of 1 with an average technical inefficiency of 0.024 for the whole census of the study.

It was also found that specific variables do not influence Saccos' inefficiency given TR slack at $95 \%$ level of confidence. A unique result to this study is that the optimizer, ilgtgamma with significant $\mathrm{p}$-value of 0.00 indicates how strong the Sacco operation is determined by management inefficiency, given TR with control variables.

Generally, this study indicates that the Saccos' specific variables given TR slack variable are not significant determinants of the technical inefficiency of Saccos in Kenya.

\section{Contribution to Theory}

This study conclusion is in line with $\mathrm{x}$-inefficiency theory which states that inefficiency of decision making unit decreases as cost reduces, and banks' intermediation theory that postulates that banks' efficiency is positively 
related to profitability. The study further supports the theory of inefficiency or x-inefficiency,

Further, it can be concluded that management influence is observed given TR slack with control variables presence as indicated by the level of Gamma. This lack of random error aspect signifies the high influence of management in Saccos, although the members' active participation may override the agency problem in management of Saccos' cash flows or resources.

\subsection{Contribution to Practice and Recommendations}

It can be concluded that the identification of strong Saccos' inefficiency or efficiency over different years can be used as benchmark. Those Saccos' unique features can be adopted as the best management practices. Further, another key contribution to practice is the evidence showing that TR slack with control variables is a key contributor in determining management inefficiencies as expressed by gamma factor. The study also concludes that large size Saccos exhibit less inefficiency characteristics and therefore the regulators should encourage merger of small or medium size Saccos in the economy. The efficiency benchmarking using DEA and stochastic mechanism are important in regulation.

\subsection{Suggestions for Further Research}

The identified limitation to this study is in the area of drilling down to specific efficient Saccos using a similar approach of study to find out at micro level what actually influences the individual inefficient or efficient Saccos in the sector. It is expected that this will invite more researches in this area as the inefficiency of Saccos over the two eras remained constant. Other reasons as to why TR slack is relevant in identifying management influence (agency problem) should further be researched beside the identification of the earnings management possibility. It may be essential to consider other predictors such as stock price real index, growth domestic product real index, income of individual members and the square of age. The comparative inefficiency study on non-deposit and deposit taking Saccos should also be studied in the future research.

\section{References}

Adams, R.B. and D. Ferreira, 2008. Women in the board room and their impact on governance and performance. Journal of Financial Economics, 94(2009): 291-309.

Banker, R.D., A. Charnes and W.W. Cooper, 1984. Some models for estimating technical and scale inefficiencies in data envelopment analysis. Management Science, 30(9): 1078-1092.

Barus, J.J., W. Muturi and P. Kibati, 2017. Effects of management efficiency on financial performance of savings and credit societies in Kenya. Journal of strategic management, 2(1): 92-104.

Battese, G.E. and T.J. Coelli, 1995. A model for technical inefficiency effects in a stochastic frontier production function for panel data. Empirical Economics, 20: 325-332. Department of Econometrics, The University of New England.

Beasley, J.E., 1996. Operation research notes: Used at imperial college. Available from Http://people.brunel.ac.uk/-mastijb/jeb/or/dea.Htm [Accessed 10 February 2013].

Brealey, R.A. and S.C. Myers, 1981. Principles of corporate finance. New York: McGraw-Hill Book Company.

Brown, R., 2006. Mismanagement or mis-measurement? Pitfalls and protocols for DEA studies in financial services sector. European Journal of Operational Research, 174: 1100-1116.

Brown, R. and I. O'Connor, 1999. Efficiency- bond of association and exit patterns in credit unions: Austrialian evidence. Annals of Public and Co-operative Economics, 70(1): 5-23.

Coelli, T., P. Rao and G. Battese, 1997. An introduction to efficiency and productivity analysis. Boston: Kluwer.

Coelli, T., P. Rao, C.J. O'Donnel and G. Battese, 2005. An introduction to efficiency and productivity analysis. New York: Spring Science and Business Media.

COK, 2010. The Constitution of Kenya. 4th Schedule. Kenya Law Reports. Available from www.kenyalaw.org.

Cooper, W.W., L.M. Seaford and K. Tone, 2007. Data envelopment analysis: A Comprehensive Text Models Application References and DEA-Solver Software, $2^{\text {nd }}$ Edition.

Cooper, W.W., L.M. Seaford and J. Zhu, 2011. Data envelopment analysis: History, models and interpretationshandbook on data envelopment analysis. International Series in Operations Research and Management Science. US: Springer, 164: 1-39.

Enarsson, S. and K. Wiren, 2005. Malawi union of savings and credit cooperatives, CGAP working group on micro insurance: Good and bad practices, Case Study, 8. MUSCO, Malawi.

Evans, A.C., 2002. The unpaved road ahead: HIV/AIDS and microfinance. An explanation of Kenya credit unions (Saccos). Research Monograph Series No. 21, Winconsin, Woccu.

Famma, 1980. Agency problems and theory of the firms. Journal of Political Economy, 88(2): 288-307.

Ferreira, D. and R.B. Adams, 2009. Women in the boardroom and their impact on governance and performance. Journal of Finance and Economics, 94(2): 291-309.

Gompers, P., J. Ishii and A. Metrick, 2003. Corporate governance and equity prices. Quarterly Journal of 
Economics, 118(1): 107-155.

Higgs, D., 2003. Review of the role and effectiveness of non-executive directors. On-line. Available from www.dti.gov.uk/cld/non-execs-review.

IMF, 2014. International monetary fund, world economic outlook database. Available from http://www.imf.org/external/pubs/ft/weo/2012/02/weodata/weorept.aspx [Accessed November 4, 2014].

Johnson, S. and M. Nino-Zarazua, 2008. A report prepared for the decentralized financial services project. Kenya and Financial Sector Deepening (FSD), Kenya. Centre for Development Studies, Univeristy of Bath.

Jondrow, J., C.A.K. Lovell, I.S. Materov and P. Schmidt, 1982. On estimation of technical inefficiency in the stochastic frontier production function model. Journal of Econometric, 19(1982): 233-238. North-Holland Publishing Company.

Kamau, A.W., 2011. Intermediation efficiency and productivity of the banking sector in Kenya, Interdisciplinary. Journal of Research in Business, 1(9): 12-26.

Karanja, J.N., 2013. The relationship between size and cost efficiency of Saccos with front office service activity in Kenya. Unpublished MSc. Finance Project, Univeristy of Nairobi.

Kivuvo, M.R. and T. Olweny, 2014. Financial analysis of Kenya's Sacco sector using Altman Z- score model of corporate bankrupty. International Journal of Business and Social Sciences, JKUCAT University, Kenya.

Leibenstein, H., (1966). "Allocative efficiency vs. X-efficiency." American Economic Review Vol.56,pp.392-415.

Magali, J.J., 2014. Variables for modelling Saccos in Tanzania. Asian Journal of Finance and Accounting, 6(1):198-215.MacroThink Institute.

Magali, J.J. and D. Pastory, 2013. Technical efficiency of rural savings and credits co-operatives in Tanzania. A DEA approach. International Journal of Management Sciences and Busienss Research, 2(12): 49-61.

Marwa, N. and M. Aziakpono, 2015. Technical and scale efficiency of savings and credit cooperatives: Evidence from Tanzania, Univeristy of Stellenbosch Businsss school, South Africa. ERSA, Working Paper No.510.

Mirie, M., 2014. The influence of members' income and conduct of Saccos in the relationship between characteristics and efficiency of Saccos in Kenya. PhD Thesis Presented at University of Nairobi.

MOCDM, 2013. Ministry of Industry, Trade and Co-operatives. Achievements of the Ministry July 2013-2014. Available from: http://www.industrialization.go.ke/index.php.

Moffat, B.D., 2008. Efficiency and productivity in Botswana's financial institutions. PhD Thesis Presented at University of Wollongong.

Njagi, G.M., E.M. Kimani and N.N. Ngugi, 2013. The impact of front office Sacco activity on Sacco performance in Kenya. A case study of Meru South and Maara district in Tharaka Nithi County in Kenya. Global Advanced Research Journal of Management and Business Studies, 2(5): 285-290.

Nyambere, F.K., 2013. Effect of credit risk management on financial performance of deposit taking savings and credit co-operative societies in Kenya. Unpublished MBA Project, University of Nairobi.

Ogebe, J.O., P. Ojah and K. Alewi, 2013. The impact of capital structure on firm performance in Nigeria. St. Augustine College of Educations. MPRA Paper No.45986.

Okibo, B. and J.M. Karagu, 2014. Financial factors influencing performance of savings and credit co-operative organization in Kenya. International Journal of Academic Research in Accounting, Finance and Management Sciences, 4(2): 295-206.

Olando, C.O., A. Jagongo and Martin, 2012. Financial practice as a determinant of growth of savings and credit co-operative societies wealth. International Journal of Business and Social Science, 3: 24:204-219.Centre for Promoting Ideas,USA.

Ozcan, Y.A., 2008. Health care benchmarking and performance evaluation. An assessment using data envelopment analyis. Available from $\mathrm{HttP}: / /$ springer.com/978-0-387-75447-5 [Accessed 17 February 2013].

Pascoe, S., J.E. Kirkley, D. Greboral and M.C.J. Paul, 2003. FAO, measuring and assessing capacity in fisheries. FAO Fisheries Technical Paper No.433/2.

Petrie, R., 2002. Rwanda credit unions member and non-member survey. Woccu Inc. Research Monorgraph Series No. 20.

SASRA, 2011. The sacco society regulatory authority, Kenya. Sacco Supervision Report for Deposit Taking Saccos, year 2011.

SASRA, 2013. The SASRA leaders' Forum. http://sasra.go.ke/index.php/new. [Accessed 30 October, 2014].

Schilit,E.,(2002). "Financial Shenanigans, $2^{\text {nd }}$ Ed., How to detect accounting gimmicks and fraud in financial reports." McGraw-Hill, New York,NY,pp.185-205.

SSA, 2008. Sacco Societies Act, 2008. Kenya Gazette No.14. Revised in 2012. [Accessed 18 February, 2015].

SSR, 2010. Sacco Societies Regulation,2010. Kenya Gazette Supplement No.39. [Accessed 11 March, 2015].

Stata, 2015. Statistics/data analysis 14.1. Statacorp LP. Available from http://www.stata.com.

Tesfamariam, K., H. Tesfay and A. Tesfay, 2013. Relative efficiency of rural saving and credit co-operatives: An application of date envelopment analyisis. International Journal of Co-perative Studies, 2(1): 16-25.

Wanyama, F.O., 2009. Surviving liberalization: The cooperative movement in Kenya. ILO; the Co-operative 
Facilty for Africa Working Paper No.10.

Wanyama, F.O., P. Develtere and I. Pollet, 2009. Reinventing the wheel? African co-operative in a liberalized economic environment. The Co-operative Facilities for Africa Working Paper No. 1.

Woccu, 2009. World council of credit unions, 2009 survey. Available from www.woccu.org/functions/viewdocument.php?id=2009 [Accessed 10 February 2013].

\section{AP. I: Operational Definition of Terms}

Common Bond Size: Number of entities through which Sacco members contribute funds (or share common interest) to the Sacco where they own shares and deposits (Researcher, 2015).

Cost Inefficiency: Saccos' excessive cost relative to the frontier. It is the difference between a benchmark and achieved performance i.e. x-efficiency (or proxy of agency costs) (Pagano et al., 1997).

Credit and Savings Co-operatives: Saccos relying too much on external source of funds than share capital, reserves and member deposits (Researcher, 2015).

DEA: Data envelopment analysis

Earnings Management: In an organization when a governor fidgets with accounting numbers in order to report higher profits and subsequently pay high dividends is what is known as earnings management (Barth et al., 2007).

Financial liberalization (FL): Measured by monetary aggregate (money supply or M3XT) to GDP (Cooper et al., 2007)(Researcher, 2015).

GOK Net Lending/Borrowing as \% of GDP (GOKLB): It measures the extent government is either putting financial resources at the disposal of other sectors in the economy (World Bank, 2014). This is a proxy for financial depth and innovative activities in Kenya.

Inefficiency (Management Inefficiency): The proportion by which the observed outcome or goal attainment fall

short of optimum level. It is represented by one-sided error term $\left(U_{r j t}\right.$ ) with a non-zero mean. $U_{r j t}$ is normally assumed to be truncated-normal (Greene, 2012; Aigner et al., 1977).

Inflation Consumer Price Index (CPI): Measures changes in prices of goods and services that households consume that affect the consumers' real purchasing power and their welfare in Kenya. CPI and GDP deflator are cross-correlated (Reis and Mankiw, 2001). A proxy for market condition.

Interest Spread (INSP): Average lending rate minus average borrowing rate. (World Bank - LNDP, 2014). $A$ proxy for risk pricing in Kenya

Liberalization Period (LP): Era of economic reforms specifically 1980s-1990s and after (Researcher, 2015).

Money Supply (M3XT): M3XT is the currency in circulation measure in Kenya that is all-encompassing (Khainga, 2014).

Post-Liberalization: After amendment of Co-operatives Act, 2004 (Researcher, 2015).

Pre-Regulation Period: 2010 and before SASRA time-from 2007 (Researcher, 2015).

Regulation Period: During SASRA from 2011 and after - to 2014 (Researcher, 2015).

SASRA License: Saccos operating FOSA were required by Saccos Societies Regulation 2010 of the Sacco Societies Act, 2008 to have applied for license by 17 June 2011 (SSA, 2008).

Slack: Amount by which either an output or input fail to attain the optimal efficiency. It is an equivalent of inefficiency level (Cooper et al., 2007).

Specific Predictor Variables: Independent study variables (variance regressors) that exclude the macro-economic independent variables (Researcher, 2015).

Stochastic Frontier Analysis (SFA): A parametric method that can test hypotheses and can accommodate single output with multiple inputs. It also uses maximum likelihood econometric estimation and decomposes the error term (e) into two components (Aigner et al., 1977).

Technically Efficient: A firm operates on the frontier of the production technology (Coelli et al., 1997).

Urban Areas: Town or Municipality area. The Urban Areas are separated from Cities according to Kenya Urban Areas and Cities Act, No.13 of 2011, revised in 2015 (Researcher, 2015). 